Kloster, Melina. Reseña de ¿Por qué Brasil, qué Brasil? Recorridos críticos. La literatura y el arte brasileños desde Argentina de Roxana Patiño y Mario Cámara (editores). Anclajes, vol. XXIII, $\mathrm{n}^{\circ}$ 2, mayo-agosto 2019, pp. 99-101

DOI: 10.19137/anclajes-2019-2327

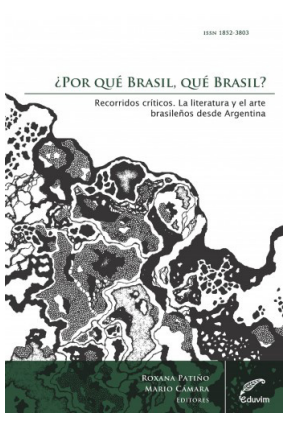

\title{
Reseña
}

\section{¿Por qué Brasil, qué Brasil? Recorridos críticos. La literatura y el arte brasileños desde Argentina}

\section{Roxana Patiño y Mario Cámara (editores)}

Villa María: Editorial Universitaria Villa María, 2017, 318 páginas.

$\mathrm{L}$ a literatura y la cultura brasileña, al menos en las dos últimas décadas, se han convertido en un foco de interés para ciertos espacios de la crítica argentina. El libro ¿Por qué Brasil, qué Brasil? Recorridos criticos. La literatura y el arte brasileños desde Argentina reúne los aportes de un coloquio realizado en la Universidad de Córdoba en el mes de agosto de 2015 sobre el tema.

El volumen se divide en tres partes: “¿Por qué Brasil? Tradiciones contaminadas y nuevos recorridos", “QQué Brasil? Lecturas anómalas, potencias políticas" y "¿Qué Brasil, qué Argentina? Vaivenes críticos". Los interrogantes traducen las inquietudes en la definición de una modalidad de lectura que busca recortar su objeto, esbozar sus objetivos y establecer categorías y herramientas de análisis válidas para aproximarse a las prácticas culturales de Brasil desde la Argentina.

Raúl Antelo, quien abre la primera parte, reconstruye tres imágenes de Brasil desde el prisma extranjero. A partir de estas figuras, el crítico problematiza el recorte de un objeto de estudio definido en términos de una imagen identitaria homogénea. En cambio, sugiere hablar de "los brasiles" y, como contrapunto, concluye sus conjeturas sobre las figuraciones de Brasil con un verso del "Hino nacional" de Carlos Drummond de Andrade: "nenhum Brasil existe".

En el artículo siguiente, Florencia Garramuño reflexiona sobre las prácticas artísticas brasileñas y su especificidad a partir del concepto de expansión (Theodor Adorno y Rosalind Krauss). Garramuño se pregunta, para el caso brasileño, qué podría aportar esta categoría históricamente datada. Para ello, compara la instalación Através (1983-1989) de Cildo Meireles, con la obra los Penetrables de Hélio Oiticica realizada en los años 1960. Considera que las prácticas culturales brasileñas actuales estallan las nociones unívocas y los campos con contornos definidos. La autora plantea, al igual que Antelo, no pensar un Brasil sino algún Brasil y, entre ellos, un Brasil en tránsito, por fuera del campo. 
Varios artículos exploran los entrecruzamientos entre artes visuales y literatura. Adriana Kogan analiza el Poema Enterrado (1959) de Ferreira Gullar. Por su parte, Luciana Irene Sastre investiga en $O$ (2014) de Nuno Ramos la experimentación con la materia y el lenguaje.

Otros investigadores actualizan la noción de entre-lugar (Silviano Santiago) en el análisis de la narrativa contemporánea. Ana D'Errico aborda la trama de la memoria en un corpus que incluye Mar Azul (2012) y Más al Sur de Paloma Vidal, A chave da casa (2007) de Tatiana Salem Levy, Volverse Palestina (2014) de Lina Meruane y El azul de las abejas (2013) de Laura Alcoba. D’Errico examina el entre-lugar que trazan estas escrituras a partir de una memoria íntima cruzada por la experiencia del viaje y la migración. Por su parte, Gabriela Cornet explora el desvanecimiento de fronteras en la novela Budapest (2003) de Chico Buarque.

Entre las propuestas de relectura de los autores clásicos, María Florencia Donadi analiza $O$ Guesa escrito por Joaquin de Andrade de Sousa. El estudio se concentra en el contrapunto entre los cantos II y X señalado por Haroldo de Campo. Y, de manera novedosa, incorpora el diálogo entre el canto X del poema de Soussandrade, que remite a la Exposición Universal de Filadelfia de 1876, y los escritos de Charles Baudelaire sobre la Exposición Universal de París en 1855. En este sentido, Donadi reflexiona junto con Walter Benjamin sobre las fantasmagorías que escenifican el poema.

El artículo de Eduardo Sterzi, el invitado brasileño al coloquio, se presenta en portugués. Sterzi retoma la obra de Carlos Drummond de Andrade y cuestiona su encasillamiento en una tradición de interpretación nacional. A partir de la categoría de pos-historia del filósofo Vilém Flusser, Sterzi lee una resistencia a la comprensión de Drummond como intérprete de una identidad nacional.

En la segunda parte del libro, predominan los artículos centrados en un corpus de estudio. En esta línea, dos autores se refieren a la obra de Clarice Lispector. Por un lado, Gabriel Giorgi explora la precariedad (Judith Butler) en la narrativa de la autora. Y por otro lado, María Rupil recupera una poética de la mirada en una intervención crítica de Lispector y dos textos ficcionales: Agua Viva (1973) y Un soplo de Vida (1978).

Juan Manuel Fernández revisita $M a$ cunaima (1928) de Mario de Andrade. El investigador se centra en las alusiones a lo culinario, tanto en la obra literaria como en las intervenciones públicas del autor. Fernández señala una "cualidad indigesta" que caracterizaría su lugar en la estética del movimiento antropofágico.

Por su parte, Nancy Calomarde articula una nueva inflexión del entre-lugar en las obras de Wilson Bueno Canoa Canoa (2009) y Diario de frontera (2010). Según su hipótesis de lectura, la escritura de Bueno esboza una "dinámica migrante" a través de múltiples modos de desplazamientos entre espacios, imaginarios, subjetividades, temporalidades y lenguas. Calomarde propone la transfrontería (geográfica, cultural, lingüística, histórica) para referirse a la territorialidad que crea la obra.

Los estudios críticos recopilados no se limitan a la literatura. En efecto, Natalia Armas y Florencia Colombetti reconstruyen las imágenes del Brasil en series fotográficas (Sebastián Salgado y Alfredo Jaar) y fílmicas (Heitor Dhalia) que documentan las condiciones de trabajo en la mina de oro de Serra Pelada ubicada en la selva amazónica. Las autoras se preguntan sobre los regímenes de visibilización de la región en el flujo mundial de las producciones artísticas y culturales. Para finalizar este segundo apartado, Laura Cabezas rastrea los vínculos entre literatura, arte 
y cristianismo en la relación afectiva entre el escritor Murilo Mendes y el pintor Isamel Nery.

En la última parte del libro, se exponen desplazamientos y enlaces críticos que dotaron de espesor al espacio común de lo argentino-brasileńo. Entre ellos, Roxana Patińo estudia las políticas de la lengua y la literatura en la revista Grumo, publicada entre 2003 y 2013. Otro punto de contacto se dibuja en la mirada sobre Brasil de Néstor Perlongher que es abordada por Mario Cámara en "Néstor Perlongher, yo mismo" y por María José Sabo en "Perlongher 'corresponsal'. El tráfico de una contracultura”. El artículo de Cámara recorre los diálogos de Perlongher con la cultura brasileña y su inserción en una cierta tradición crítica de pensamiento sobre lo brasileño. En cambio, Sabo se enfoca en las intervenciones del escritor en el ámbito político y literario argentino.

En esta última sección del libro, la obra de Clarice Lispector reaparece en un artículo de Constanza Penacini. En efecto, el punto de partida del estudio es la actualidad y el impacto de la autora que se verifica en diferentes espacios y disciplinas de todo el mundo en los últimos quince años. El interés por Lispector también se evidencia en este volumen en el que hay tres estudios dedicados a su obra. Por su parte, Penacini enlaza esta profusión de lecturas con ciertas categorías del filósofo Baruch Spinoza que reconoce en la escritura de la autora.

Los cruces entre fronteras, lenguas y orígenes se multiplican en la propuesta de Paloma Vidal que cierra el libro. La autora traza desde lo discursivo una cartografía posible de lo argentino-brasileño que conjuga miradas propias y ajenas.

En resumen, los artículos reunidos ofrecen un panorama de las lecturas actuales, tanto de obra clásicas como contemporáneas. Además, y quizás allí radique su mayor apuesta, demuestran un acercamiento a lo brasileño que busca evadir las fronteras de las literaturas y las tradiciones críticas nacionales.

\section{Melina Kloster}

UNIVERSIDAD NACIONAL DE LA PAMPA FACULTAD DE CIENCIAS HUMANAS INSTITUTO DE INVESTIGACIONES LITERARIAS Y DISCURSIVAS, IILYD ARGENTINA ORCID: 0000-0002-2833-3312 